\title{
Small and Medium-sized Enterprises - Progress and Impact in National Economics of Slovak Republic - Changes of Economic Tools in 2013- 2015 Period
}

\author{
Helena Strážovská \\ Faculty of Commerce, University of Economics in Bratislava, Slovakia
}

Copyright $(\mathcal{C} 2016$ by authors, all rights reserved. Authors agree that this article remains permanently open access under the terms of the Creative Commons Attribution License 4.0 International License

\begin{abstract}
After the Velvet Revolution in the former Czechoslovakia in 1989, the economy was faced with a problem of building money- goods relationship in a new way. An important part of the abandonment of a socialist way of economy had become the transition of an ownership in the hands of private sector individuals. Also significant was the return of a property to the former owners of so called 'restitution.' The economic theory monitored and supported this process in particular with the development of a control theory. In addition to the theory, respectively the acceptance of new economic categories, it was necessary to address the organizational aspects of the business sector. Thus in 1993 the Slovak theory began to deal with small and medium- sized enterprises. In 2004, Slovakia entered the European Union, and in 2009 it entered the Eurozone as well. These historical changes had a significant impact on both the theory and economic reality. The Slovak economy and economic theory and the special theory of small and medium-sized businesses took the content of economic categories from developed economies, particularly the USA and the European Union. Research activities in the field of small and medium-sized enterprises began in 1993 and intensified after 2004. In the text of our article, we think about these processes and evaluate the activities and results of small and medium- sized enterprises, seeing those levels of growth.
\end{abstract}

Keywords History and Setting in Slovakia from Early 90s, SMEs = Small and Medium- sized Enterprises/ Entrepreneurship, SMEs and Employment in Slovakia, Key Changes of Economic Instruments from 2015, Summary of Benefits and Wages

\section{Introduction}

Foundation and development of small and medium- sized enterprises in the Slovak Republic was first recorded in the early 90s. Despite of the socialist history of Slovakia, along with business development there was also progress in the economic theory. While in theory it was possible to draw from foreign materials, in reality errors have occured several times caused by the lack of experience.

The birth of small and medium- sized enterprises in Slovakia was conditioned by several factors.

We mean the gradual disintegration of large govertmentowned enterprises in the first wave of large-scale privatization, leaving a large number of small and medium-sized enterprises. An important fact was the return of properties to the citizens called 'restitution.' Finally, the liberalization of trade relations which caused the foundation of more small and medium- sized enterprises with foreign investment. If we evaluate small and medium- sized enterprises in terms of their long-term development, we must take the facts into account.

\section{Methodology}

The analytical part of the text has been processed based on the results of the questionnaire survey. The results were used from approx. 200 questionnaires in several periods. The results were processed by methods of economic statistics with intermediate values, dynamic series and board index numbers. Basically, we approached the text from the analytical point of view, while we watched primarily the process of knowledge and we used comparison. The final phase was the use of synthesis methods but it is not an easy connection- making into a whole but more like creation of qualitatively new insights into economic processes.

\section{History and setting in Slovakia from Early 90s}

Slovakia started to pay significant attention to small and 
medium-sized enterprises (SMEs) after 1989-1990, i.e. after the Velvet Revolution.

From an economic point of view, it meant respect for commodity - financial relations and at the same time, it was the beginning of development of the theory of SMEs

A few historical reversals [6] to understand current trends with particular attention to SMEs...

From the historical point of view on economics of Slovak republic it seems that it has went through many changes on its way from central- planned economy in socialist period to market economy in 1989 and acceptance of relevant categories. Velvet revolution in 1989 brought a change in the economy of former Czechoslovakia. In 1993 Slovakia became independent from Czech Republic. Another significant point in the history occurred when Slovakia in 2004 became a member of the European Union. In 2009 Slovakia entered Eurozone which means also applied Euro as a new currency. The crisis' chain reaction hit Slovakia as well with a delay and there were a couple of changed in the economic rules. Slovakia in 2013 is 5 years in the Eurozone and so there is evaluating in process. Later on in 2014 there has been an impact of Ukraine crisis what has made it necessary to adopt new economic rules.

The amount of changes [8] and most of all the direction and focus towards European Union for small and medium-sized enterprises meant that the Slovak government had aligned their application of European rules of small and medium- sized enterprises with rules of European Commission.

\section{What Is an SME?}

The years $1989-1990$ are considered in Slovakia as the start and development of SMEs, this process began in Europe in 1971 at Bolton's conference. In Slovakia, therefore, this process was delayed for 20 years.

\section{The Bolton Report 1971 Defined SMEs}

SMEs have relatively small market share and practically cannot significantly influence the market. They are managed by owners - entrepreneurs, family owners or by co-owners and not through a formal management structure. SMEs are independent enterprises, they don't form a part of a larger company.

\begin{tabular}{|c|c|c|c|}
\hline & Microenterprises & $\begin{array}{c}\text { Small } \\
\text { enterprises }\end{array}$ & $\begin{array}{c}\text { Medium } \\
\text { enterprises }\end{array}$ \\
\hline Headcount & $1-9$ & $10-49$ & $50-249$ \\
\hline $\begin{array}{c}\text { Annual } \\
\text { turnover } \\
\text { and/or }\end{array}$ & $\begin{array}{c}\text { Less than 2 million } \\
\text { Euros }\end{array}$ & $\begin{array}{c}2-10 \text { million } \\
\text { Euros }\end{array}$ & $\begin{array}{c}10-50 \text { million } \\
\text { Euros }\end{array}$ \\
\hline $\begin{array}{c}\text { Balance } \\
\text { sheet }\end{array}$ & $\begin{array}{c}\text { Less than 2 million } \\
\text { Euros }\end{array}$ & $\begin{array}{c}2-10 \text { million } \\
\text { Euros }\end{array}$ & $\begin{array}{c}10-43 \text { million } \\
\text { Euros }\end{array}$ \\
\hline
\end{tabular}

Small and medium sized enterprises in European Union from January 1st 2005 European Commission 2002 (What is SME? - Small and medium- sized enterprises)

\section{The Definition of Small \& Medium- sized Entrepreneurship}

This publication is dealing with self-employed individuals who run their own business \& also with small and medium-sized entrepreneurship so it is suitable to include not just the definition of entrepreneurship but the whole small \& medium-sized entrepreneurship [9].

In Slovakia according to section 2 in Commercial code, law nr. 513/1991 defines entrepreneurship as following: Entrepreneurship is understood as a constant action done independently by entrepreneur using his own name \& responsibility where the business is made to generate profit. An Entrepreneur according to this law is either a business entity registered in business register or a business entity that is running their business based on self-employed individual certificate. Another explanation according to the law what an entrepreneur is that it is a business entity that is running their business based on other certificate than self-employed individual certificate according to the special rules or a natural person that is running agricultural production and is registered in register according to the special rule.

Into the business register it is compulsory to register as a legal entity or natural person at one's own request. Special rules are understood as activities that are not self-employed entrepreneurship activities but they are entrepreneurship activities. It regards to some entrepreneurship activities which require special education, for example medical and veterinary education. They are detailed by paragraph of self-employed individual law. By law the main conditions to obtain the self-employed individual certificate are the age when the self-employed individual has to be 18 or older to start a business. The person has to have a competence for legal acts and he or she could not commit a crime before which is also described as blamelessness.

It is possible to divide self-employed entrepreneurships according to acquisition into announced and licensed, according to requirements into activity of craftsmen, contract-based and contract free. Described types of self-employed entrepreneurship are detailed by attachment 1 (activity of craftsmen) and 2 (contract-based) of selfemployed entrepreneurship law.

From the perspective of European economics and also economic theory the attention to the small and medium-sized entrepreneurs has been given after 1971 when Bolton report was created. According to Bolton report small and medium-sized enterprises are defined as small and medium-sized enterprises that have relatively small market share and practically cannot significantly influence the market. Small and medium-sized enterprises are managed by owners - entrepreneurs, family owners or co-owners but not using a formal management structure. Small and medium-sized enterprises are independent enterprises, they don't form a part of a larger company.

Small and medium-sized enterprises nowadays in Slovakia represent approximately $90 \%$ of all enterprises and they are categorized as legal entities and natural persons. 


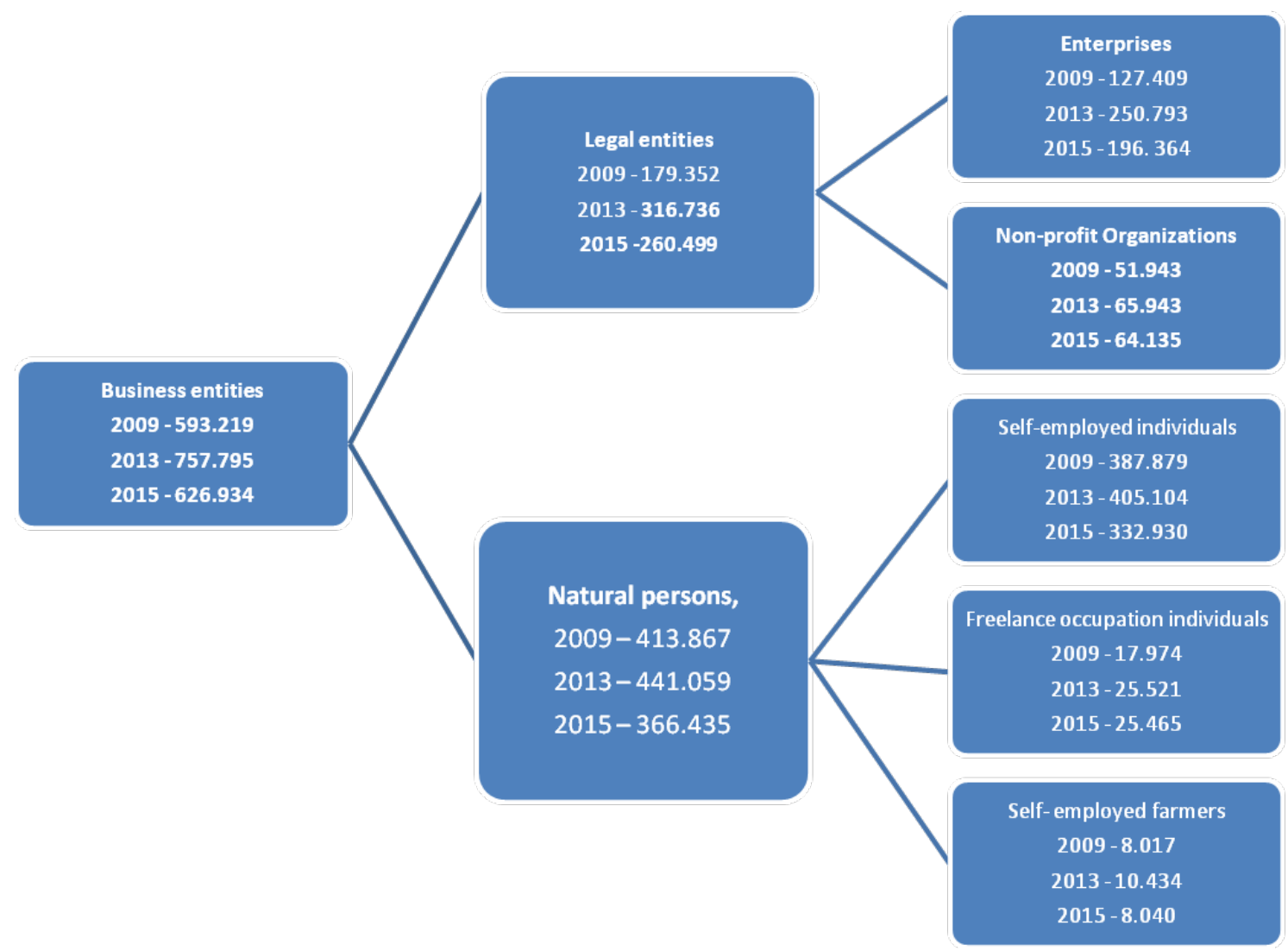

Business entities at the time of entry of Slovakia into Eurozone in 2009 and five years after the entrance into Eurozone in 2013 ... First 6 mounts 2015.

Slovak legislation [3] divides the form of entrepreneurship into natural persons and legal entities. There are two types of natural persons depending if they are or are not registered in business register. Legal entities represent companies which can be a public company, commander, public company limited, joint stock company, legal entities founded according to the European law, enterprises and organizational components of international enterprises, collective farm or association.

It is also possible to divide small \& medium- sized enterprises from quantitative aspect according to the size of the profit, individual fund type, market share, production amount or retail amount, sales and other but the most common method is number of employees.

European commission in its recommendation, nr. 2003/361/EC valid until 1.1.2005 uses combination of quantitative \& qualitative classificatory criteria's of number of employees, yearly turnover, balance sheet total \& autonomy of enterprise. Based on the named criteria small \& medium- sized based enterprise is described as a company which is connected with the economic activity, it has less than 250 employees, its yearly turnover does not cross 50 million Euros, or its balance sheet total does not cross 43 million Euros and the enterprise is autonomic

Word "autonomic" is understood as it does not own shares in other companies and other companies do not own shares of this company. If it owns less than $25 \%$ of shares of single or multiple other companies and other companies own less than $25 \%$ shares of this company. If it owns in total less than $25 \%$ of shares of connected companies and they own less than $25 \%$ shares of this company. If other companies own between $25 \%$ and $50 \%$ of their own shares which are not connected and there are different types. The first one is public investment corporations, companies which put funds into joint company or collective farms with shares less than 1,25 million Euros. The second one is Universities \& non-profit research centers. Then there are institutional investors, including regional developing funds and the last ones are local autonomic organizations with yearly budget less than 10 million Euros and with less than 5000 citizens.

Small \& medium- sized enterprises are in the next step sorted by size. There are micro enterprises, small enterprises and medium- sized enterprises. Micro enterprises have between 1- 9 employees, yearly turnover up to 2000000 Euros \& balance sheet total up to 2000000 Euros. Small enterprises have between 10 - 49 employees, yearly turnover up to 10000000 Euros \& balance sheet total up to 10000 000 Euros. Medium- sized enterprises have between 50- 249 employees, yearly turnover up to 50000000 Euros \& balance sheet total up to 43000000 Euros.

Entrepreneurship can be understood as an economic entrepreneurship where the main goal is to increase a default value by adding resources. From psychological perspective it is self- fulfillment and reaching life goals. The definition is possible to understand also from sociological perspective as 
creating welfare or raising the number of available jobs. And finally it is possible to understand that from a legal perspective as it is declared in business law- book.

Because of balanced understanding of basic vocabulary we will state the definition for word "entrepreneurship. "Entrepreneurship (entrepreneurial ability) is the ability to search, create and use opportunities which are located in entrepreneurial environment so that the business entity (individual or company) would make profit.

\section{Small \& Medium- sized Enterprises in Slovakia}

If the year 1989 was considered in Slovakia to be the development of small and medium- sized enterprises, unfortunately there has to be said that this process has started in Europe in 1971 at Bolton's conference. In Slovakia therefore, this process was delayed for 20 years.

Small and medium- sized enterprises represent about $90 \%$ of all businesses in Slovakia. From a more detailed analysis of the legal entities in Slovakia, we can clearly see that the Slovak economy is developing in favor of the increase in the number of legal entities, with one exception, and that is a problem of the growth or decrease of the number of entrepreneurs and economic self-employed farmers. The analysis of this group you can be found in the paper.

For example, in 2009 we have had already 387.876 self-employed people and their number grew to 415.000 . The global economic crisis caused the significant decrease of their number (each year by about 10000 under 400000). Slowly their number gets to the pre-crises level. At the end of 2014, the number of self-employed people was 400.104 while it should be stressed that before joining the European Union, in 2003 there were 306.356 self-employed people in Slovakia traders, but their numbers continued to grow.

Another fact is that the change of economic rules substantially implemented already in 2013 meant that many self-employed people changed their legal form to the limited company.

The main reason was that they considered the application of new economic rules much simpler for that group.

In spite of early hardships the establishment of a business in the early nineties has become a popular activity. The development of entrepreneurial sector show Tables 1 a \& 1 b:

Table 1a. Number of natural persons in Slovakia in years 2001-2006

\begin{tabular}{|c|c|c|c|c|c|c|}
\hline & 2001 & 2002 & 2003 & 2004 & 2005 & $* 2006$ \\
\hline Natural persons - entrepreneurs & 303506 & 297400 & 329720 & 360378 & 367094 & 388246 \\
\hline Self-employed individuals & 279597 & 273322 & 306356 & 336640 & 344870 & 364185 \\
\hline Freelance occupation individuals & 12187 & 12368 & 13044 & 13683 & 12752 & 15175 \\
\hline Self- employed farmers & 11722 & 11710 & 10320 & 10055 & 9472 & 8886 \\
\hline
\end{tabular}

Table 1b. Number of natural persons in Slovakia in years 2007-2012

\begin{tabular}{|c|c|c|c|c|c|c|}
\hline & $* 2007$ & $* 2008$ & $* 2009$ & $* 2010$ & $* * 2011$ & $* * 2012$ \\
\hline Natural persons - entrepreneurs & 399641 & 418221 & 413867 & 410308 & 402325 & 387452 \\
\hline Self-employed individuals & 374382 & 392841 & 387876 & 384202 & 375722 & 359575 \\
\hline Freelance occupation individuals & 16725 & 17189 & 17974 & 18378 & 10069 & 20382 \\
\hline Self- employed farmers & 8534 & 8191 & 8017 & 7728 & 7534 & 7495 \\
\hline
\end{tabular}

Source: Statistic annual publication 2006, Page 391; *Statistic annual publication 2011, Page 359; **Statistic annual publication 2013 , Page 375

The Tables describe that the number of natural persons has fluctuating but growing trend. Only after economic crisis triggered by financial crisis back from 2008 has stopped this growth and returned it 2 years back. The table already analyzes detailed period of crisis years. It is noticeable that the descent is not global. In some segments there is no descent visible and surprisingly there can even be seen a growth. The structure of some segments according to SK NACE classification looked in 2012 as follows [1]: 


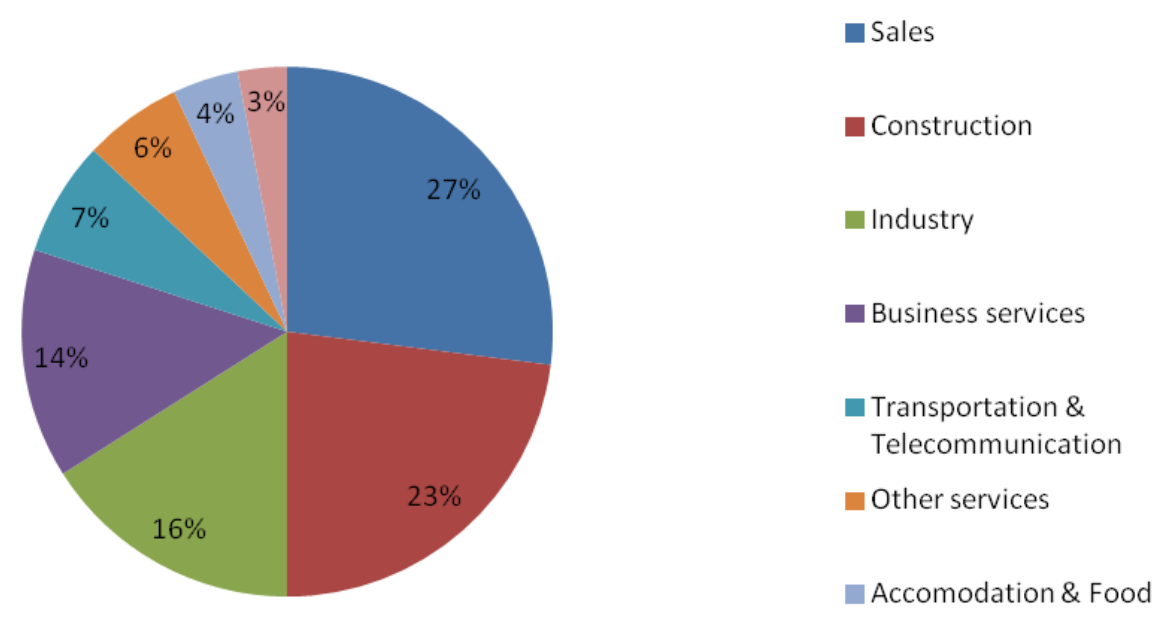

Diagram 1.1. Division of self- employed individuals according to segments

Percentual division of Freelance occupation individuals in 2011 shows the following diagram:

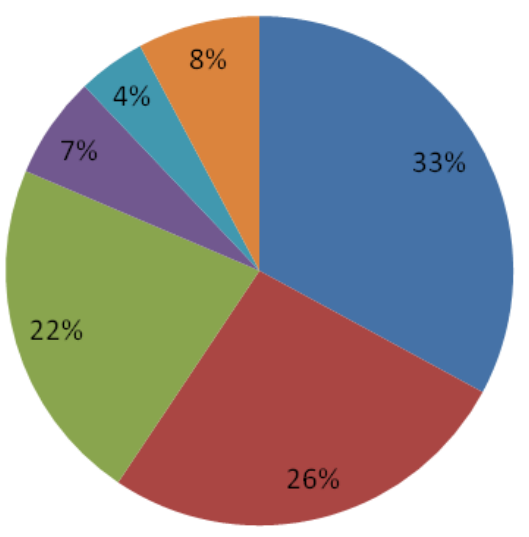

\author{
- Support activities in insurance \\ business \& pension assurance \\ Ambulance \& dentist services \\ Legal services \\ Architectonic \& engineering \\ services \\ Veterinary services \\ Other services
}

Diagram 1.2. Division of freelance occupation individuals

To better show the real count of small \& medium- sized enterprises in individual regions we have decided to compare them with number of citizens.
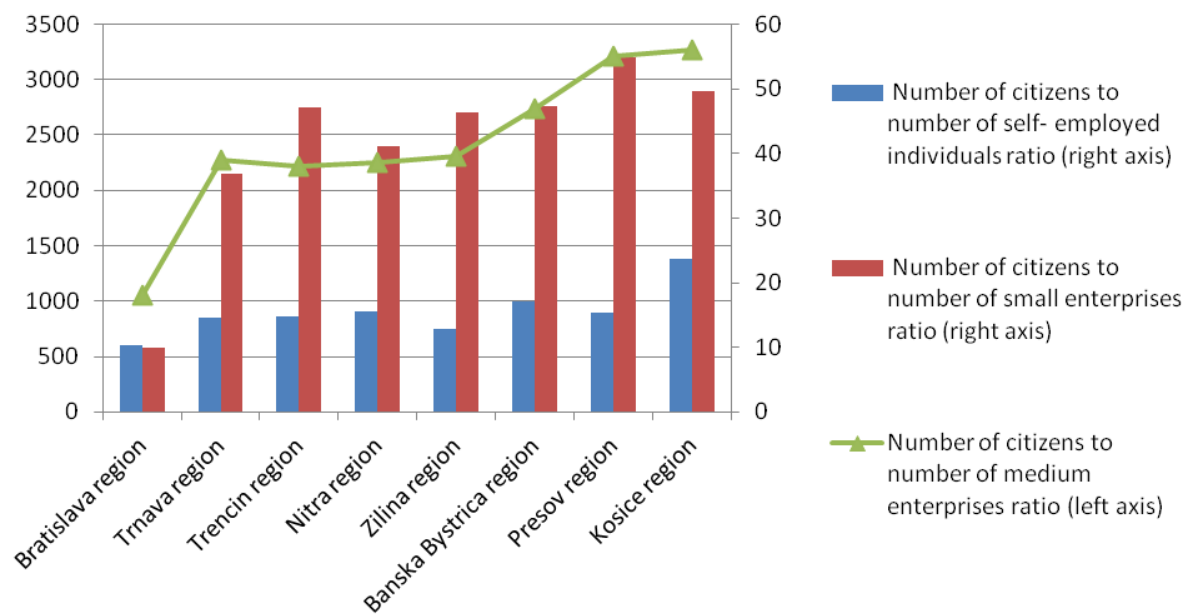

Diagram 1.3. Number of self- employed, small \& medium- sized enterprises to citizens ratio 
On the other hand there were many factors [2] that made it harder for executing entrepreneurial activities or discouraged people from establishing a business.

Those factors includes unsatisfactory legal environment which has problems with accurate fulfillment of legal standards, unclear interpretation, often changes, insufficient penalizing of the competitors that were using unethical practices, prolonged law enforceability. Another factor is bureaucracy, more specifically prolonged process of getting different permits, branch tax rules, unclear insurance system, disproportionately more responsibilities when employing new labor force, unappropriated approach of government authorities. Next variable is acquisition of funds, bank loan for strategic plans, insufficient liquidity needed for overcoming short unfavorable descents. Also a problem is insufficient knowledge about market as a whole, unfamiliarity with marketing practices. And last but not least, is not dealing well with mental stress, everyday fight over customers, problems with suppliers, not dealing well with a job without any social securities.

At last it is important to add that there are flaws on the business side as well which could be mentioned as well \& here are some of them: the overbalance of short- term goals over long- term goals, missing strategic thinking. Another flaw represents not acting according to moral values in relation with business partners, customers \& government, not paying charges \& bills, not paying off loans, and not caring about customer's interest. Also the problem sometimes lies in lower educational level of managers.

During the last quarter of century small \& medium- sized enterprises took in Slovakia the same place in national economy just like in other developed countries of European Union. In the whole European union small \& medium- sized enterprises form around $99,8 \%$ of all enterprises where micro enterprises have $91,5 \%$, small enterprises have $7,3 \%$ $\&$ medium- sized enterprises have $1,1 \%$. When it comes to labor force in private sector, small \& medium- sized enterprises make $67,1 \%$ of the employment but in other segments (for example in metallurgy, construction \& in furniture manufacturing) even more than $80 \%$. In more detailed view in case of micro enterprises they employ $29,6 \%$ of labor force, small enterprises employ $26,9 \%$ \& medium- sized enterprises give jobs to $16,8 \%$ of the labor force. Large enterprises employ in private sector around one third of the labor force, more specifically $32,9 \%$.

The benefits of small \& medium- sized enterprises in economic world of any country, including that of Slovakia are important. Their importance comes from different reasons such as that small $\&$ medium- sized enterprises are the most important source for increasing employment. They also use local resources whether they are human or natural. They suppress social problems \& social tension. Small and medium- sized enterprises are able to employ less- educated labor force in high significance. They lean on regional traditions, mostly doing business in sectors which are connected to the region. Entrepreneurs are sources of new ideas. Small \& medium- sized enterprises are innovators of products \& services. They are also able to build more personal relationship with their customers.

Small and medium-sized enterprises [7] represent about $90 \%$ of all businesses. From more detailed analysis of the legal entities in Slovakia, we can clearly see that the Slovak economy is developing in favor of the increasing number of natural persons, with one exception, and that is a problem of the growth or decrease of the number of self-employed individuals and self-employed farmers that tend to react on changes of the economic tools very rapidly.

At the end of 2014, the number of self-employed people was 400.104 while it should be stressed that already before joining the European Union, in 2003 there were 306.356 self-employed individuals in Slovakia and their numbers continued to constantly grow. For example, in 2009 we have had already 387.876 self-employed individuals and their number grew to 415.000 . However the global economic crisis caused a significant decrease in their number (each year by approximately 10.000), today their number is under 400.000. Slowly their number is getting to the pre-crisis level.

Another fact is that the change of economic rules substantially implemented already in 2013 meant that many self-employed individuals changed their legal form from self-employed to the limited company which meant they had the form of legal entity instead of individual. The main reason was that they considered the application of the new economic rules more beneficial and simpler for that group. This was just an apparent event.

The important change in the Slovak economy, like it was already stated before, had become years 2013, 2014 and 2015 when there were new economic rules applied so the content of the multiple economic tools was changed.

The most important changes in economic rules in Slovakia include increase of the corporate taxes from $19 \%$ to $23 \%$ in 2014 and then $22 \%$ in 2015. Another significant change was the implementation of the progressive tax system of the natural persons who earn more than 3.310 euros a month where $25 \%$ tax rate applies, also the implementation of the individual 5\% tax rate for the selected government individuals. Next thing that has changed was the restriction of the option of applying $40 \%$ of the costs for self-employed individuals up to 5.040 euros yearly or 420 euros monthly. Then there was the implementation of the option of getting tax bonus only when tax payer is getting minimum wage set by law from only active income. And finally, the implementation of the nontaxable part of the base for wife (husband) who lives with the tax payer in the same household and takes care of an infant child living with tax payer in the household is up to the 3 years of age of the child.

Reaction of the economic practice wasn't always positive on listed changed especially from small and medium-sized enterprises' perspective just like we show in the scheme above. Small and medium-sized entrepreneurs have left the market or they have changed their legal form. The effect of these changes came up already in first half 2015 when the number of self-employed individuals went down to 332.930 with $97,2 \%$ of the total number of the natural persons compared to the previous period. 


\section{Individuals - Entrepreneurs structure as of June 30th 2015}

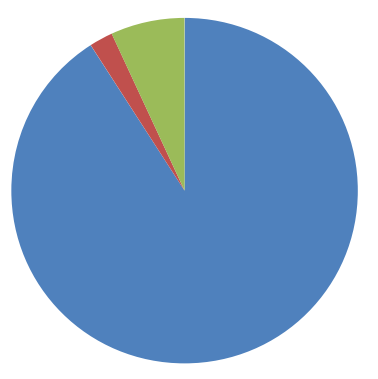

Self-employed individuals

- Self-employed farmers

Freelance occupation individuals

\begin{tabular}{|c|c|c|c|}
\hline 1. & $\begin{array}{l}\text { The growth in the economy. In practice it means more } \\
\text { investments and work. }\end{array}$ & $2,5 \%$ & In $20142,2 \%$ growth. \\
\hline 2. & Expected employment growth. & & Slower growth than in 2014 - double growth was expected. \\
\hline 3. & $\begin{array}{l}\text { Real salary growth after taking account of public sector } \\
\text { (teachers, doctors, clerks) }\end{array}$ & & $\begin{array}{c}\text { The change means increase even after taking account of the } \\
\text { price growth. }\end{array}$ \\
\hline 4. & Price growth & & In 2014 the prices did not increase at all. \\
\hline 5. & $\begin{array}{l}\text { Growth of the tax level and increased ratio of the taxes payed } \\
\text { by companies }\end{array}$ & $\begin{array}{c}190 \\
\text { million } \\
\text { Euros }\end{array}$ & $\begin{array}{l}\text { After the implementation of the new rules for depreciation, } \\
\text { the building depreciation will be prolonged from } 20 \text { years } \\
\text { to } 40 \text { years and other parts will be prolonged as well. }\end{array}$ \\
\hline
\end{tabular}

To the entire view of the most important changes in the economic tools valid in 2015 belongs: (5 most important changes in economic sphere of Slovakia and how we expect them in 2015).

In this statement it is necessary to mention a couple of things about the Slovak economy in general such as in 2014 the real income level was $4 \%$ higher in comparison with 2013. After 1990 there were weak generations coming up, there were only about 50 to 60 thousand children born yearly. Lastly the citizens prefer to purchase the goods with long-term consumption, mainly flats and furniture.

\section{Key Changes of Economic Instruments from 2015}

Slovakia was faced with the task of reducing the deficit below $3 \%$ of GDP. It was decided to change economic instruments [4].

\section{Changes in Legislation Regulating Trade Business}

One of them was the cancelation of the license of trade business (repeal of licensed trade) and the change in the division of trade business. Trade business from 1st of June 2010 licensed, are classified as regulated. Since 1st of June 2010 trade business is divided into handicraft, regulated and unregulated. Another cancelation was the cancelation of licenses and concession documents and their replacement by certificates. There were changes in charges for reporting. One-stop point provided the extension of services, offered more. The waiting time for the issue of certificates was shortened. The maximum length of the interruption trade was determined for 3 years. There was the introduction of a six-month extension of the practice for craft. The overall bureaucracy was reduced.

By the amendment of the law, trade licensing offices were given new competencies - they set so called "single contact point". At this point, a starting entrepreneur can fulfill all administrative requirements associated with a trade license. And at the same time he can register for health insurance and the tax office.

\section{Changes in Tax - Contribution System}

The amendment of maximum amount of flat expenses was set to 5040 per year, $€ 420$ per month. There has been the introduction of progressive income taxation with two tax rates $-19 \%$ and $23 \%$. Limiting tax relief for wife/husband has been applied.

The tax preferred voluntary contributions to II. Pillar is in amount of $2 \%$. New rules for depreciation losses have been introduced. Another change occurred in the area of contributions where it increased and united the maximum base of assess. The method of calculating contributions has been changed as well.

The minimum pensionable earnings of self-employed have been increased. The obligation to pay contributions to 
revenue from the agreements has been introduced. Next change was the concession from contribution. Another was automatic termination of voluntary insurance.

\section{Changes in VAT}

The introduction of the so- called 'Control statements' was applied. Since the beginning of 2014, there is an obligation to communicate electronically exclusively. The control statement should serve to match operations between taxable persons. Domestic sector self-assessment taxation was put into practice.

\section{Changes in the Grants for Business}

The conditions to receive grant for the establishment of trade have been tightened. The way of the payment of the grant was changed in amounts of $2-60 \%$ upon signing the agreement and $40 \%$ after one year of running business. The office is now not obliged to prepare the business. Re-utilization of the grant is possible only after 8 years.

\section{Changes in Accounting}

In order to reduce the administrative burden on business in 2013 the Act on Accounting was amended. The amendment defines a new kind of entity - so called 'micro accounting unit.'

\section{Other Changes in Economic Rules Coming into Force in 2015 [10]}

New virtual cash register - from April $1^{\text {st }} 2015$ all the doctors and taxi drivers will have to issue receipts for payments received.

\section{Changes in Income Tax}

Key things are depreciation of property, expenses shall be limited, cancelation of certain tax expenditures - obviate the possibility of reducing a tax expenditure provisions, such as unbilled deliveries, holidays, etc. Also it is important to mention the limitation of representation expenses, tax prepayments, more effective administration in postponement of tax declaration. Tax bonus - the change of the amount will be recalculated at each 1st of January and not on 1st of July as it was before. The amount of the tax bonus will be frozen for the whole year. An Entrepreneur will have to tax his income from immaterial damage.

\section{Proposed Changes in VAT}

New rules for summary statement were put in- monthly when the trade value exceeded 50000 euro for the last calendar quarter. Control statement has a new term - on the date of the tax declaration or 25 days after the end of the tax period.

\section{Proposed changes in Contributions}

The changes did not miss this area either. There are now higher health insurance contributions, higher social insurance contributions and voluntary insurance is limited.

\section{Major Changes in Economic Rules in Slovakia}

The tax rate for companies had been increased from 19 to $23 \%$. A progressive income taxation for natural persons from 3310 euro by tax rate of $25 \%$ has been introduced as well as a special tax rate of $5 \%$ for the selected state officials. Also the possibility to apply for $40 \%$ flat expenses for tradesmen to a maximum of $€ 5040$ per year or $€ 420$ per month. There was an introduction of the possibility to apply the tax bonus under condition the taxpayer reaches the statutory minimum from so called "active income" only. The application of tax relief for the wife (husband), who lives in the taxpayer's household and taking care of the small child (till 3 years of age) also living with the taxpayer in the household.

\section{The Most Significant Changes in Depreciation from 1st of January 2015 (in EUR)}

Cars will be depreciated otherwise the maximum price of the car which can be write off by entrepreneur and because of that end in a loss, will be 48 thousand euros. They cannot write off more even if the care was more expensive. In practice it means that more than 48,000 will have to depreciate if the car gets to the loss.

A shorter depreciation of technologies reduction of time for the depreciation period from 12 to 8 years: An entrepreneur can annually depreciate a larger amount and pay lower tax. However, this change will not be applied to all industries and machines, only to specific ones. For example, for turbines, furnaces, burners, gas generators, machinery for metallurgy and so on.

A longer depreciation of non-production buildings: For example, administrative buildings, but also hotels, can be depreciated up to 40 years instead of 20. During that long period they will be able to write off smaller amounts. In practice, they will pay more tax.

\section{Summary of Benefits and Wages}

The amendment [5] to the law on the assistance in material need from January $1^{\text {st }} 2015$ introduces overlapping of assistance in material need and wages. Now entitled for assistance in material need are those long-term unemployed people who find work and earn not more than twice the minimum wage. The aim is that people who work have more income than people who remain in material need. Firms may ask for contributions to youth. Companies can apply for a higher contribution from the state to create jobs for young people.

From January $1^{\text {st }} 2015$, an amendment to the Employment Services Act was adopted with aim to promote the employment of young people after graduation or after leaving early or at the end of compulsory schooling did not receive regular paid employment. Contributions to support jobs creation employers can be received through the labor offices.

In 2014 the unemployment rate went down by 1,5\% in comparison with 2013 because there was a growth of the domestic demand and also because of the aging of the 
population. Every year there are approximately about 100.000 people going into retirement who were born in years 1953-1955. Yearly there were about 100000 children born.

To paint the whole picture about Slovak economy [11] at the start of 2015 (first and second quarter of 2015) it is appropriate to state some important economic characteristics. It regards of the annual difference compared to the previous reference period. In the $1^{\text {st }}$ quarter of 2015 the GDP was $3,1 \%$ and the inflation rate was $-0,1 \%$. The employment rate in the selected sectors looked like this. In the industry it was $1,9 \%$, in construction it was $-1,1 \%$, in retail trade it reached $-0,6 \%$ and in wholesale it moved to $0,5 \%$. In production the industry production index reached $6,4 \%$ and the industry production was $26,0 \%$. As far as citizens' economic activity goes the number of working was around 2,6 million.

Average monthly wage in selected sectors (Euros)

\begin{tabular}{|c|c|c|}
\hline $\mathbf{1 .}$ & Industry Total & 937 \\
\hline $\mathbf{2 .}$ & Construction & 595 \\
\hline $\mathbf{3 .}$ & Sale and repair of the motor vehicles & 845 \\
\hline $\mathbf{4 .}$ & Wholesale & 808 \\
\hline $\mathbf{5 .}$ & Retail trade & 591 \\
\hline $\mathbf{6 .}$ & Accommodation & 623 \\
\hline $\mathbf{7 .}$ & Food and beverage service activities & 375 \\
\hline $\mathbf{8 .}$ & Information and communication & 1.752 \\
\hline $\mathbf{9 .}$ & Selected market services & 806 \\
\hline
\end{tabular}

\section{Results}

Analyses done in the recent period mainly serve the process of learning the Slovak business process which has a relatively short period of its existence.

The sector of self- employed individuals positively develops within microenterprises. They represent the largest number of enterprises in Slovakia. Another change happened in the form of natural persons - private farmers as a first sector partially defined as family businesses in agriculture. We have already mentioned that in Slovakia a family business is currently not defined as a legal form.

Negative aspects of business processes that are almost continuously present in the Slovak economy are frequently changes in legislation, relatively high tax burden, inadequate penetration of foreign markets, lack of legal background for family businesses and still operating bureaucracy and the attempts for tax evasion.

Despite this, in practice, the positive elements predominate. The proposed changes of economic categories in favour of the national economy which will turn into reality from 2016 should help the total development in Slovakia.

\section{Discussion}

The development of small and medium- sized enterprises in Slovakia began after the Velvet Revolution in 1989. This was due to a complete change in the political atmosphere, the desire for personal fulfillment and using conditions provided by a free society.

Slovakia since 1989 introduced a number of changes in existing economic instruments especially for small and medium- sized enterprises .Important are those that will be introduced from 2016. Among them, the minimum wage will be provided in size of 407 euros. It is more than in the past but very little because of the growth in living standards.

The number of unemployed in Slovakia is still in the range of $\pm 350,000$ people, but the unemployment rate dropped from the original $14 \%$ to $12 \%$.

The following problems solves so called ' 3 . Social package' of the prime minister of Slovakia. One may ask whether all this is sufficient. In the business sphere for the first time in Slovak economy appears Hybrid Company with elements of a stock company and public limited company. It can be set up for just 1 euro - with the validity from 2017 . Some entrepreneurs are thrilled while the others ask questions.... There are no experiences with a similar company. It was established based on the efforts to improve the legal forms of companies.

\section{Conclusions}

The Slovak economy is gradually coming to the favorable numbers as evidenced by the results of the national economy in 3Q 2015. The European Commission has evaluated the Slovak economy as a rapidly growing and praised its achievements.

New economic rules and change of the content of economic instruments should help Slovakia in 2018 to have a balanced budget. Another objective is to decrease the unemployment rate.

Small and medium- sized enterprises as an engine of the Slovak economy will be its economic performance and a positive factor for the growth of the national economy.

The Government is committed to support the development of small and medium- sized enterprises which resemble different social packages set by Prime minister of Slovakia. Small and medium- sized enterprises are involved in GDP about $50 \%-60 \%$ and in the employment about $75 \%$. It would be desirable to a greater extent than has previously been linked to foreign markets. It would require a fixed and unchanging legislative background so that the development would be gradual.

In our text, which is primarily informative nature of the development of the Slovak economy, we pursued the objective to bring the current process of development which is still very short compared to the developed economies.

Small and medium- sized enterprises whose legal milestones were laws on private business in 1990 and later laws on the transfer of an ownership of the government and of the government properties to private individuals.

A focus to the development of the small and mediumsized enterprises in Slovakia is dedicated by continued close 
economic and organizational and legislative support. Inclusion of small and medium- sized enterprises in the European Union integration means on one hand benefits from the advanced economic environment, on the other hand opens up new and attractive business opportunities for activive and concept- managed small and medium- sized enterprises. Slovakia aims to move forward on the road offered.

\section{References}

[1] Lubomíra Strážovská, Malé a stredné podnikanie a rodinné podnikanie, Crámium, s.r.o., Nové Zámky, ISBN 80-968443-7-7, 2004

[2] Lubomíra Strážovská, Helena Strážovská, Monika Krošláková, Podnikanie formou rodinných podnikov, Sprint2, Bratislava, ISBN 978-80-969927-0-6, 2008

[3] Helena Strážovská, Lubomíra Strážovská, Ladislav Bažó a kol., Podnikanie malých a stredných podnikov, Sprint2, Bratislava, ISBN 80-968443-7-7, 2013

[4] Helena Strážovská a kol., Ekonomické procesy v obchodnom podnikaní, Sprint2, Bratislava, ISBN 978-80-89710-15-7, 2015
[5] Helena Strážovská, L’ubomíra Strážovská, Ladislav Bažó, Monika Krošláková, Malé a stredné podnikanie (zmena ekonomických nástrojov 2016 v tlači), 2016

[6] Helena Strážovská, Lubomíra Strážovská, Skúsenosti Slovenskej republiky vo vybraných oblastiach po zavedení eura. In: V. Cibáková a kol., Veřejná správa v kontextu př́pravy a vstupu státu do eurozóny, Masarykova univerzita: Ekonomicko- správní fakulta, Brno, ISBN 978-80-210-4979-6, 2009

[7] Helena Strážovská, L'ubomíra Strážovská, Hodnotenie malého a stredného podnikania v Slovenskej republike. 5. kapitola. In: Kolektív autorů 2012. Vývoj a stav malého a středního podnikání v České republice a Slovenské republice, Business school, Ostrava, ISBN 978-80-7410-057-4, 2012

[8] Elena Strážovská, L'ubomíra Strážovská, Mária Pachingerová, Anna Sirotková, Podnikanie ŠÚ SR, Mercury, Bratislava, 2009

[9] Helena Strážovská, Zborník vedeckých statí, In Design, s.r.o., Nové Zámky, ISBN 978-80-970404-1-3, 2011- 2012

[10] Helena Strážovská, Lubomíra Strážovská, Zsolt Horbulák, Netradičné formy zamestnávania v Mad’arsku a na Slovensku, výskum, Ekonomika cestovného ruchu a podnikanie č.1, Publishing House, Bratislava, ISSN 1337-9313, 2015

[11] Helena Strážovská, L’ubomíra Strážovská, Ekonomika Slovenska v roku 2014, vybrané vzt’ahy a výsledky, Ekonomika cestovného ruchu a podnikanie, Publishing House, Bratislava, ISSN 1337-9313, 2015 